\title{
Urine Protein Measurement
}

National Cancer Institute

\section{Source}

National Cancer Institute. Urine Protein Measurement. NCI Thesaurus. Code C74760.

The determination of the amount of protein present in a urine sample. 